PRACE NAUKOWE UNIWERSYTETU EKONOMICZNEGO WE WROCLAWIU

\title{
Joanna Krasodomska
}

Uniwersytet Ekonomiczny w Krakowie

e-mail: joanna.krasodomska@uek.krakow.pl

\section{RAPORTOWANIE ZINTEGROWANE A SPOLECZNA ODPOWIEDZIALNOŚĆ PRZEDSIĘBIORSTW}

\section{INTEGRATED REPORTING VS. CORPORATE SOCIAL RESPONSIBILITY}

DOI: $10.15611 / \mathrm{pn} .2018 .503 .24$

JEL Classification: M41, M14

Streszczenie: Koncepcja sprawozdawczości zintegrowanej powstała w 2010 r., a jej wytyczne $(<\mathrm{IR}>$ Framework) zostały opublikowane przez Międzynarodową Radę ds. Zintegrowanego Raportowania (International Integrated Reporting Council - IIRC) w 2013 r. Początkowo była ona silnie związana ze społeczno-środowiskowymi aspektami działalności przedsiębiorstw, z którymi przez wielu autorów nadal jest utożsamiana. Celem artykułu jest przybliżenie krytycznych głosów, zgodnie z którymi związki zintegrowanego raportowania ze zrównoważonym rozwojem (sustainable development) czy społeczną odpowiedzialnością biznesu (Corporate Social Responsibility, CSR) znajdują się obecnie na dalszym planie. Raport zintegrowany ma przede wszystkim informować o procesie tworzenia wartości i jest adresowany do dostarczycieli kapitału (inwestorów). Jest on dodatkowym raportem, możliwym do opracowywania przez spółki obok sprawozdań finansowych i raportów społecznych. W zamierzeniu autorki rozważania zawarte $\mathrm{w}$ artykule przyczynią się do rozwoju naukowej dyskusji nad sprawozdawczością zintegrowaną i prowadzenia badań w tym zakresie.

Słowa kluczowe: sprawozdawczość zintegrowana, CSR, zrównoważony rozwój, raport.

Summary: The concept of integrated reporting originated in 2010 and its guidelines $(<\mathrm{IR}>$ Framework) were published by the International Integrated Reporting Council (IIRC) in 2013. Initially, the concept was strongly linked to the socio-environmental impacts of companies and it is still identified with them by many authors. The aim of the paper is to present the opinions of some critics who claim that connotations of sustainable development or corporate social responsibility carried by the concept of integrated reporting have recently lost significance. The integrated report is primarily to inform about the process of value creation and it is addressed to capital providers. It is an additional report, which can be prepared by companies along with financial statements and CSR (social) reports. The author hopes the article will contribute to the scientific debate about the concept of integrated reporting and encourage scientific research in this area.

Keywords: intregrated reporting, CSR, sustainable development, report. 


\section{Wstęp}

Rosnąca złożoność działalności przedsiębiorstw i związane z tym luki w regulacjach rachunkowości doprowadziły do powstania dodatkowych norm prawnych, standardów, kodeksów, wytycznych czy dobrych praktyk dotyczących sprawozdawczości. W efekcie spowodowało to zwiększenie zakresu informacji ujawnianych przez spółki w postaci coraz dłuższych i bardziej skomplikowanych sprawozdań finansowych i sprawozdań z działalności, dodatkowych oświadczeń dotyczących ładu korporacyjnego i obszernych raportów społecznych [IIRC 2011, s. 4]. Przekonanie o tym, że współczesna sprawozdawczość jest pełna braków, fragmentaryczna i niespójna, stało się przesłanką podjęcia wysiłków na rzecz jej przebudowy. W ich wyniku powstały nowe koncepcje raportowania, z których obecnie najszerzej propagowana jest sprawozdawczość zintegrowana. Jej wytyczne $(<\mathrm{IR}>$ Framework) zostały opublikowane w 2013 r. przez Międzynarodową Radę ds. Zintegrowanego Raportowania (International Integrated Reporting Council - IIRC).

Sprawozdawczość zintegrowana jest coraz szerzej praktykowana przez spółki oraz podejmowana $\mathrm{w}$ pracach badawczych, również przez polskich autorów, przy czym jest często wiązana ze zrównoważonym rozwojem (sustainability) czy społeczną odpowiedzialnością biznesu (Corporate Social Responsibility, CSR)1. O ile początki powstania idei zintegrowanego raportowania faktycznie miały z nimi związek, wydaje się, że w obecnej formie ma ona odmienne priorytety. Analiza wytycznych z 2013 r. pozwala zauważyć odsunięcie koncepcji zrównoważonego rozwoju przyświecającej IIRC od momentu jej powstania na dalszy plan oraz umiejscowienie w jej centrum tworzenia wartości dla inwestorów.

Celem artykułu jest wykazanie, że propagowana przez IIRC koncepcja zintegrowanej sprawozdawczości nie może być bezkrytycznie wiązana z ideą zrównoważonego rozwoju/CSR. Podstawę przeprowadzonych rozważań stanowią publikacja J. Flowera na łamach czasopisma Critical Perspectives on Accounting oraz artykuły będące wynikiem rozpoczętej przez niego tym samym naukowej dyskusji [Thomson 2015; Adams 2015; Dumay i in. 2016; Rodrigue 2015; Alexander, Blum 2016].

\section{Od raportu Brundtland (1987 r.) do raportu zintegrowanego (2013 r.)}

W tzw. Raporcie Brundtland [United Nations 1987] zrównoważony rozwój (sustainable development) jest definiowany jako zaspokajanie potrzeb obecnego pokolenia bez umniejszania szans przyszłych pokoleń na ich zaspokojenie. Rozwój ten wymaga zintegrowania działań w trzech kluczowych obszarach, którymi są: wzrost gospodarczy, rozwój społeczny i ochrona środowiska [United Nations 2002]. CSR jest

${ }^{1}$ Por. m.in. [Bek-Gaik 2015; Dyczkowska 2015; Kwiecińska 2015; Mazurowska 2015; Remlein 2015, 2016]. 
natomiast określana przez Komisję Europejską jako „odpowiedzialność przedsiębiorstw za ich wpływ na społeczeństwo" [Komisja Europejska 2011]. W literaturze przedmiotu niekiedy CSR jest uznawana za odpowiedź biznesu na wyzwania zrównoważonego rozwoju i uważa się, że praktykowana na poziomie przedsiębiorstw przyczynia się do niego w skali globalnej.

Z omawianymi wyżej koncepcjami łączy się problem raportowania społecznego. Raportowanie społeczne to ujawnianie danych pozafinansowych, czyli kwestii z obszaru środowiskowego, społecznego oraz ładu korporacyjnego. Raport społeczny przedstawia wyniki społecznie odpowiedzialnego prowadzenia działalności gospodarczej w danym okresie. Powinien zatem definiować okres sprawozdawczy, zawierać oświadczenia dotyczące przyjętych w tym zakresie celów, strategii, polityk oraz uzyskanych wyników w sposób pozwalający na ich porównanie w kolejnych latach [FOB 2017]. Najszerzej stosowanymi wytycznymi w zakresie raportowania społecznego są standardy GRI (Global Reporting Initiative), tzw. Sustainability Reporting Guidelines.

Problem możliwości integracji coraz obszerniejszych raportów (rocznych i społecznych) sporządzanych przez rosnącą liczbę przedsiębiorstw stał się przedmiotem dyskusji, w której wzięli udział we wrześniu 2009 r. w Londynie Sir M. Peat (A4S²), P. Druckman (A4S, FEE Sustainability Group) i M.E. King (GRI). Prowadzone przez nich rozmowy dotyczyły także roboczej wersji książki przygotowanej przez R. Ecclesa z Harvard Business School i M. Krzusa z Grant Thorton pt. One Report [Eccles, Krzus 2010]. Bezpośrednim następstwem tego spotkania było powstanie nowej koncepcji - raportowania zintegrowanego (integrated reporting, dalej $<\mathrm{IR}>$ ). W sierpniu $2010 \mathrm{r}$. GRI i A4S ogłosiły utworzenie International Integrated Reporting Committee (IIRC), a w 2011 r. opracowano pierwszą wersję ram $<$ IR $>$ (Discussion Paper on $<\mathrm{IR}>$ ) [Dumay i in. 2016, s. 167]. Ostateczna wersja wytycznych $(<\mathrm{IR}>$ Framework) została opublikowana w grudniu 2013 r. Zgodnie z nimi raport zintegrowany zawiera informacje o tym, w jaki sposób strategia, ład korporacyjny i wyniki działalności spółki w kontekście otoczenia, w którym działa, pozwalają jej tworzyć wartość w krótkiej, średniej i długiej perspektywie. Raport ten jest przede wszystkim adresowany do dostarczycieli kapitału, których ma wspierać w procesie podejmowania decyzji w zakresie jego alokacji [IIRC 2013c, s. 7].

W 2015 r. J. Flower w artykule zatytułowanym wymownie: The International Integrated Reporting Council: A story of failure przedstawił krytykę wytycznych IIRC (podzielaną również przez innych autorów, por. Rodrigue 2015), zwracając uwagę na m.in.: przesunięcie na dalszy plan koncepcji zrównoważonego rozwoju, ukierunkowanie na inwestorów oraz fakt, że wbrew zapowiedziom raport zintegrowany stał się jedynie kolejną korporacyjną publikacją.

${ }^{2}$ Prince's Accounting for Sustainability Project (A4S), rozpoczęty przez Karola, Księcia Walii w 2004 r. w celu opracowania rozwiązań wspomagających podejmowanie decyzji i sprawozdawczość przedsiębiorstw, które uwzględniałyby długoterminowe konsekwencje podejmowanych działań w kontekście idei zrównoważonego rozwoju. 


\section{Zrównoważony rozwój a $<$ IR $>$ Framework}

Jak zaznaczono w opublikowanym w $2010 \mathrm{r}$. w związku z powołaniem IIRC komunikacie prasowym [IIRC 2010], głównym celem organizacji tworzących ją, czyli GRI i A4S, była poprawa sprawozdawczości z zakresu zrównoważonego rozwoju. Stwierdzono w nim, że w gestii IIRC leży stworzenie globalnie akceptowanych ram rachunkowości z uwzględnieniem założeń tej koncepcji. Powinny one połączyć (zintegrować) informacje finansowe, środowiskowe, społeczne oraz z zakresu nadzoru korporacyjnego w jasny, zwięzły, spójny i porównywalny sposób w formie zintegrowanego raportu. Intencją przyświecającą tej inicjatywie była pomoc przedsiębiorstwom w opracowywaniu wyczerpujących i zrozumiałych informacji o wynikach ich działalności, co pozwoliłoby im sprostać potrzebom kształtującego się współcześnie, bardziej zrównoważonego globalnego modelu gospodarczego [Flower 2015, s. 2].

W obowiązujących obecnie wytycznych ich cel sformułowano już nieco inaczej. Jest nim bowiem poprawa jakości informacji dostępnych dostarczycielom kapitału, tak aby umożliwić im jego efektywną alokację. Tym samym, jak piszą J. Dumay i in. [2015, s. 167], <IR > nie ma obecnie już nic wspólnego ze zrównoważonym rozwojem, gdyż odeszła od tej koncepcji w stronę całkowitej koncentracji na biznesie $\mathrm{i}$ inwestorach. Argumentem popierającym zmianę orientacji IIRC może być wynik przeprowadzonej przez J. Flowera analizy wybranych dokumentów opublikowanych przez tę organizację w latach 2010-2013 (tabela 1).

Tabela 1. Odwołania do sustainability $\mathrm{w}$ dokumentach IIRC

\begin{tabular}{|l|c|c|c|}
\hline \multicolumn{1}{|c|}{$\begin{array}{c}\text { Dokumenty opublikowane } \\
\text { przez IIRC }\end{array}$} & $\begin{array}{c}\text { Liczba nawiązań } \\
\text { do zrównoważonego } \\
\text { rozwoju* }\end{array}$ & $\begin{array}{c}\text { Liczba } \\
\text { stron }\end{array}$ & $\begin{array}{c}\text { Liczba nawiązań } \\
\text { na stronę }\end{array}$ \\
\hline Komunikat prasowy 2010 & 13 & 3 & 4,3 \\
\hline Dokument dyskusyjny 2011 & 27 & $22^{* *}$ & 1,2 \\
\hline$<\mathrm{IR}>$ Framework 2013 & 1 & $27^{* * *}$ & 0,04 \\
\hline
\end{tabular}

* terminy takie jak: sustainability, sustainable, sustain

** bez przykładów

*** bez streszczenia i słowniczka

Źródło: opracowanie własne na podstawie [Flower 2015, s. 8].

$\mathrm{Z}$ danych zaprezentowanych $\mathrm{w}$ tabeli 1 wynika, że w komunikacie prasowym z 2010 r. 12 razy nawiązano do zrównoważonego rozwoju, a w (dużo dłuższym) dokumencie dyskusyjnym z 2011 r. - 27 razy. Natomiast w obowiązujących obecnie wytycznych [IIRC 2013c] termin sustainability (lub pokrewne) pojawia się jedynie trzy razy. Po raz pierwszy w miejscu, w którym jest mowa o tym, że $<$ IR $>$ ma przyczyniać się do stabilności finansowej i zrównoważonego rozwoju (s. 2). Po raz drugi, gdzie zaznacza się, że zintegrowany raport nie jest kompilacją innych opracowań 
(m.in. raportów zrównoważonego rozwoju) (s. 8), i po raz trzeci, przy okazji mowy o KPI i ich publikacji w sprawozdaniach finansowych czy raportach zrównoważonego rozwoju (s. 30). Wyniki te w opinii autora dowodzą, że IIRC porzuciła początkowo obrany cel kształtowania ram sprawozdawczości uwzględniającej ideę zrównoważonego rozwoju.

Zmniejszenie zainteresowania zrównoważonym rozwojem przez IIRC J. Flower tłumaczy tym, że już w momencie jej utworzenia połowę członków stanowili wykwalifikowani księgowi, w opinii autora zdeterminowani, aby przejąć kontrolę nad inicjatywą, która zagroziła ich ugruntowanej pozycji [por. także Alexander, Blum 2016]. Rada, licząca 40 członków, obejmowała bowiem przedstawicieli IASB, FASB, IFAC, IOSCO, Wielkiej Czwórki oraz dyrektorów finansowych wpływowych korporacji międzynarodowych. Nie zasiadali w niej i nadal nie zasiadają przedstawiciele Greenpeace, Friends of Earth czy środowisk akademickich skupiających osoby prowadzące badania z zakresu rachunkowości społecznej i środowiskowej, takich jak Centre for Social and Environmental Accounting. J. Flower [2015, s. 2] zwraca także uwagę na fakt odejścia z IIRC twórcy koncepcji Triple Bottom Line (TBL) J. Elkingtona ${ }^{3}$.

Rezygnacja IIRC z uwzględniania koncepcji zrównoważonego rozwoju jest także widoczna w publikacji pt. Capitals. Background Paper for $<I R>$, w której zaprezentowano różnice pomiędzy raportowaniem społecznym a zintegrowanym [IIRC 2013a, s. 17]. Jak zaznaczono, doświadczenie z zakresu raportowania społecznego może okazać się pomocne we wdrożeniu raportowania zintegrowanego, ale istnieją pewne kluczowe różnice pomiędzy tymi dwiema formami sprawozdawczości. Po pierwsze, sprawozdawczość społeczna jest skierowana do szerszego grona odbiorców niż $<\mathrm{IR}>$, która jest adresowana głównie do inwestorów, w szczególności podejmujących decyzje w długoterminowej perspektywie. Po drugie, koncentruje się ona na wpływie przedsiębiorstwa na środowisko, społeczeństwo i gospodarkę w większym stopniu niż na kapitałach i ich wpływie na tworzenie wartości w czasie, co jest przedmiotem zainteresowania $<\mathrm{IR}>$. W związku z tym sprawozdawczość ta $\mathrm{W}$ mniejszym stopniu niż $<\mathrm{IR}>$ skupia się na relacjach między kapitałami czy ich strategicznym znaczeniu dla tworzenia wartości. Prezentuje też inne, dodatkowe ujawnienia, które nie spełniają w wystarczającym stopniu wymogu istotności koniecznego dla ich ujęcia w zintegrowanym raporcie.

\section{Inwestorzy czy interesariusze?}

Kolejnym podniesionym przez J. Flowera problemem są adresaci zintegrowanego raportowania. W opinii autora IIRC padła ofiarą regulacyjnych nacisków, co spowodowało, że jej wytyczne zawiodły jako inicjatywa na rzecz dobra publicznego, dla

3 Jak piszą J. Dumay i in. [2016, s. 167], J. Elkington, początkowo popierający <IR >, nie szczędził jej później krytyki, twierdząc, że niektóre spółki, które eksperymentowały ze zintegrowaną sprawozdawczością, zamiast raportów w duchu koncepcji TBL stworzyły „monstra Frankensteina”. 
którego w pierwszej kolejności powstała, i ma obecnie na celu jedynie przynoszenie korzyści dominującej grupie interesu, jaką są inwestorzy.

Jak wynika $\mathrm{z}<\mathrm{IR}>$ Framework, raport zintegrowany jest przede wszystkim adresowany do dostarczycieli kapitału, których ma wspierać w procesie podejmowania decyzji w zakresie jego alokacji. Informacje w nim zawarte mogą także służyć innym interesariuszom: pracownikom, klientom, dostawcom, kontrahentom, społecznościom lokalnym, władzom legislacyjnym, nadzorcom [IIRC 2013c, s. 7]. W opinii J. Flowera rozszerzenie grona interesariuszy ma jednak na celu jedynie sprawienie wrażenia, że IIRC uwzględnia również ich cele. Tak naprawdę z kontekstu wynika, że absolutne pierwszeństwo mają inwestorzy, a pozostali interesariusze są jedynie środkiem do osiągnięcia nadrzędnego celu, jakim jest zapewnienie im dobrobytu.

$\mathrm{W}$ centrum koncepcji $<\mathrm{IR}>$ znajduje się proces tworzenia wartości. Jak zwraca uwagę J. Flower [2015, s. 5], wartość może być różnie rozumiana i może być też tworzona dla różnych podmiotów. Może nią być „,wartość dla społeczeństwa” (podejście zgodne $\mathrm{z}$ przyjętym $\mathrm{w}$ ramach rachunkowości społeczno-środowiskowej) „wartość dla interesariuszy” (podejście zgodne z teorią interesariuszy) czy też „wartość dla obecnych i przyszłych pokoleń" (w duchu koncepcji zrównoważonego rozwoju). Zawarte w wytycznych stwierdzenie „dostarczyciele kapitału finansowego" wyraźnie sugeruje koncentrację wytycznych na „,wartości dla inwestorów”. Oznacza to, według autora, odsunięcie na dalszy plan pozostałych interesariuszy, którzy stają się jedynie środkiem do osiągnięcia przez przedsiębiorstwo nadrzędnego celu, jakim jest maksymalizacja bogactwa właścicieli kapitału (akcjonariuszy). Według J. Flowera [2015, s. 14] początkowe podejście IIRC uwzględniało wartość dla interesariuszy, czego wyrazem było ujęcie jako jednej z zasad $<\mathrm{IR}>$ reagowania na potrzeby interesariuszy i ich zaangażowania w sprawy spółki (responsiveness and stakeholder inclusiveness). W dokumencie (konsultacyjnym) [IIRC 2013b] pozostało jedynie reagowanie na potrzeby interesariuszy. Ostatecznie w $<\mathrm{IR}>$ Framework wspomina się o relacjach z interesariuszami (stakeholder relationships). Jest to termin neutralny, wskazujący na niewielkie zaangażowanie interesariuszy w proces zintegrowanego raportowania, oraz na to, że ich potrzeby, interesy i oczekiwania są uwzględniane, lecz prawdopodobnie w mniejszym stopniu niż w początkowym ujęciu IIRC.

\section{Zintegrowany raport - jedynie dodatkowy dokument opracowywany przez spółki}

Raport zintegrowany, zgodnie z pierwotnym założeniem, powinien być osadzony na gruncie rachunkowości i zakorzeniony w koncepcji zrównoważonego rozwoju. Mocne strony rachunkowości, takie jak oparcie na ilościowych, wiarygodnych informacjach, istotność, wiarygodność, porównywalność i zewnętrzna weryfikacja, powinny pozwolić na przełożenie koncepcji zrównoważonego rozwoju na język zrozumiały dla osób podejmujących decyzje w przedsiębiorstwie [Thomson 2015, s. 19]. Jak zauważa I. Thomson [2015], wydaje się on jednak mieć obecnie więcej 
wspólnego z praktykami stosowanymi w ramach rachunkowości zarządczej, takimi jak np. Balanced Scorecard, niż wprowadzeniem zrównoważonego rozwoju do codziennych biznesowych działan.

Warto też podkreślić, że początkowo IIRC proponowała zintegrowany raport jako podstawowy raport przedsiębiorstwa, zastępujący raczej niż uzupełniający dokumenty wymagane do tej pory [IIRC 2011, s. 6]. Z obowiązującej wersji wytycznych wynika jednak, że może on być osobnym raportem, częścią innego raportu [IIRC 2013c, s. 8] lub może odwoływać się do innych raportów. Raport zintegrowany jest więc dodatkowym raportem, możliwym do opracowywania przez spółki obok sprawozdań finansowych i raportów społecznych. W opinii J. Flowera IIRC przyczynia się tym samym do stanu, który tak gorliwie krytykowała w $2011 \mathrm{r}$. przytłoczenia odbiorców informacjami upublicznianymi przez spółki. Przystaje ona także na możliwość publikacji zagadnień społecznych i środowiskowych w odrębnym raporcie społecznym, pozostawiając problem raportowania społecznego w gestii ustaleń GRI.

\section{Zakończenie}

Koncepcja zintegrowanej sprawozdawczości, jaka wyłania się z przywołanego w artykule komunikatu z 2010 r. [IIRC 2010] ogłaszającego utworzenie IIRC, jest wyrazem idealistycznego dążenia do opracowania nowego modelu rachunkowości, który promowałby zrównoważony rozwój, uwzględniał zagadnienia społeczne i ochronę środowiska. W marcu 2013 r. GRI i IIRC ogłosiły podpisanie porozumienia o pogłębianiu współpracy na rzecz transformacji przyszłej sprawozdawczości przedsiębiorstw. Zaznaczono w nim autonomiczność obu organizacji, ale także, że sprawozdawczość z zakresu zrównoważonego rozwoju jest filarem zintegrowanego raportowania [GRI, IIRC 2013]. Wydźwięk komunikatu opublikowanego kilka miesięcy później w związku z wydaniem IR Framework [IIRC 2013d] jest już nieco inny. Wyraźnie zasugerowano w nim, że IIRC jest przyjazna biznesowi i inwestorom i nie proponuje rozwiązań, których strony te by nie zaakceptowały - bardziej rewolucyjnych i obciążających je zmian w sprawozdawczości. Nie odniesiono się w niej także w żaden sposób do współtwórców oryginalnej koncepcji, a zarazem samej IIRC - A4S i GRI [Flower 2015, s. 16].

J. Flower jednoznacznie stwierdza, że początkowe aspiracje IIRC nie zostały osiągnięte, poniosła ona porażkę i odeszła od tego, co było jej pierwotnym celem. Z pomysłu zakorzenionego w koncepcji zrównoważonego rozwoju powstały w jego opinii wytyczne słabe, niejasne, skoncentrowane na biznesie i umocowane na gruncie ideologii kapitalistycznej. Autor winą za ten stan rzeczy obarcza księgowych i przedstawicieli praktyki gospodarczej chcących zachować „sprawozdawcze status quo”. Wprowadzenie zintegrowanego raportowania w pierwotnej formie oznaczałoby dla nich ryzyko utraty dominującej pozycji jako grupy zawodowej kształtującej sprawozdawczość przedsiębiorstw, a na spółki nałożyłoby dodatkowe obowiązki w zakresie gromadzenia informacji o niefinansowych wynikach prowadzonej działalności. 
Trudno nie uznać powyższych stwierdzeń za prawdziwe. Zdaniem autorki należy jednak zgodzić się ze stwierdzeniem C. Adams, że sama konfrontacja oryginalnych celów IIRC z zawartymi ostatecznie w wytycznych z 2013 r. nie może być wystarczającą przesłanką dla ogłoszenia porażki tej organizacji [Adams 2015, s. 23]. Mimo odejścia od idei zrównoważonego rozwoju zmusza ona bowiem księgowych do podjęcia dyskusji nad tym, co należy rozumieć przez wartość, dla kogo ma ona być tworzona, oraz dostrzeżenia znaczenia niefinansowych czynników w procesie jej tworzenia. Chociaż w wytycznych IIRC CSR zeszła na dalszy plan, to jej przejawem są kapitały: ludzki, naturalny, społeczny i relacyjny. Adresatami zintegrowanych raportów są co prawda inwestorzy, ale jest wśród nich rosnąca grupa inwestorów odpowiedzialnych społecznie, czego wyrazem jest dynamicznie rozwijający się rynek SRI (Socially Responsible Investments). Wydaje się też, że GRI jest nadal bliskim partnerem IIRC, czego dowodzi ich współpraca w ramach Corporate Leadership Group on Integrated Reporting [2017].

W Polsce można zaobserwować wzrost zainteresowania koncepcją $<\mathrm{IR}>$. Większość autorów opublikowanych dotychczas prac raczej jest jej przychylna, wskazując na korzyści płynące z jej związków z CSR i podając przykłady polskich spółek praktykujących raportowanie zintegrowane. Krytyka koncepcji $<\mathrm{IR}>$, wyrażana do tej pory, wywodziła się bowiem raczej z pytania, czy rachunkowość powinna zajmować się zrównoważonym rozwojem (CSR) [Kamela-Sowińska 2009]. Obecnie może, zdaniem autorki, prowadzić do rozwoju dyskusji naukowej na temat $<$ IR $>$ w dwojaki sposób. Po pierwsze, może stanowić zachętę dla naukowców reprezentujących rachunkowość i nieuznających zagadnień społecznych i środowiskowych za przedmiot jej zainteresowania do bliższego przyjrzenia się istocie $<\mathrm{IR}>$. Po drugie, ci z nich, którym bardziej odpowiadało pierwotne stanowisko IIRC, mogą zacząć działać na rzecz powrotu koncepcji <IR> „do korzeni”. Niezależnie od pobudek, rozwój badań naukowych w obszarze $<\mathrm{IR}>\mathrm{w}$ Polsce jest w ocenie autorki zjawiskiem wskazanym i pożądanym. Należy bowiem podkreślić, że raportowanie zintegrowane to koncepcja, która wciąż ewoluuje. Wpływ na nią mają wyniki badań naukowych, a także czynne angażowanie się $\mathrm{w}$ prace IIRC poprzez przesyłanie uwag do jej propozycji oraz członkostwo w $<$ IR $>$ Academic Network i czynny udział w dyskusji prowadzonej na forum LinkedIn.

\section{Literatura}

Adams C., 2015, The International Integrated Reporting Council: A Call to Action, Critical Perspectives on Accounting, vol. 27, s. 23-28.

Alexander D., Blum V., 2016, Ecological economics: A Luhmannian analysis of integrated reporting, Ecological Economics, vol. 129, s. 241-251.

Bek-Gaik B., 2015, Sprawozdawczość zintegrowana - wybrane problemy, Zeszyty Naukowe Uniwersytetu Szczecińskiego, Finanse, Rynki Finansowe, Ubezpieczenia nr 873(77), s. 479-491.

Corporate Leadership Group on Integrated Reporting, 2017, https://www.globalreporting.org/resourcelibrary/GRI\%20CLGir\%202017.pdf (dostęp: 30.05.2017). 
Dumay J., Bernardi C., Gurthie J., Demartini P., 2016, Integrated reporting: A structured literature review, Accounting Forum, vol. 40, s. 166-185.

Dyczkowska J., 2015, Raportowanie zintegrowane - obecne i przyszłe kierunki badań oraz oczekiwane korzyści, [w:] Micherda B. (red.), Sprawozdawczość i rewizja finansowa. Uwarunkowania ekonomiczne, społeczne i regulacyjne, Wydawnictwo Uniwersytetu Ekonomicznego w Krakowie, Kraków, s. 94-104.

Eccles R., Krzus M., 2010, One report: Integrated reporting for a sustainable strategy, Wiley \& Sons, Hoboken, New York.

Flower J., 2015, The International Integrated Reporting Council: A Story of Failure, Critical Perspectives on Accounting, vol. 27, s. 1-17.

FOB, 2017, http://odpowiedzialnybiznes.pl/hasla-encyklopedii/raportowanie-spoleczne (dostęp: 15.05.2017).

GRI, IIRC, 2013, Memorandum of Understanding: IIRC and GRI - 01 February 2013, http://integratedreporting.org/wp-content/uploads/2013/02/MoU-IIRC-GRI-20130201-1.pdf?dm_i=4J5,1BERL, 2NHPCK,4GJ8M,1 (dostęp: 30.05.2017).

IIRC, 2010, http://integratedreporting.org/wp-content/uploads/2011/03/Press-Release1.pdf (dostęp: 30.04.2017).

IIRC, 2011, Towards Integrated Reporting, Communicating value in the 21st Century.

IIRC, 2013a, Capitals Background Paper for $<I R>$.

IIRC, 2013b, Consultation Draft of the International Integrated Reporting Framework.

IIRC, 2013c, The International $<I R>$ Framework.

IIRC, 2013d, http://integratedreporting.org/news/the-international-ir-framework-released-with-businessand-investor-support/ (dostęp: 30.05.2017).

Kamela-Sowińska A., 2009, Sprawozdawczość społeczna. Czy to jeszcze rachunkowość?, [w:] Problemy współczesnej rachunkowości, Oficyna Wydawnicza Szkoła Główna Handlowa, Warszawa.

Komisja Europejska, 2011, http://ec.europa.eu/transparency/regdoc/rep/1/2011/PL/1-2011-681-PLF1-1.Pdf (dostęp: 10.05.2017).

Kwiecińska K., 2015, Wiarygodność zintegrowanego raportu przedsiębiorstwa społecznie odpowiedzialnego, Studia Oeconomica Posnaniensia, vol. 3, no. 1.

Mazurowska M., 2015, Analiza porównawcza wytycznych Global Reporting Initiative oraz International Integrated Reporting Committee, Studia Oeconomica Posnaniensia, vol. 3, no. 1.

Remlein M., 2015, Doświadczenia polskich grup kapitałowych w zakresie zintegrowanej sprawozdawczości, Studia Oeconomica Posnaniensia, vol. 3, no. 1.

Remlein M., 2016, Koszty i korzyści prezentowania dokonań przedsiębiorstwa społecznie odpowiedzialnego $w$ zintegrowanym sprawozdaniu, Zeszyty Naukowe Politechniki Częstochowskiej. Zarządzanie, nr 23(2), s. 51-59.

Rodrigue M., 2015, The International Integrated Reporting Council: A Story of Failure; 'But Does Sustainability need Capitalism or an Integrated Report' a Commentary on 'The International Integrated Reporting Council: A Story of Failure' by Flower, J.; The International Integrated Reporting Council: A Call to Action, Social and Environmental Accountability Journal, vol. 35(2), s. $128-129$.

Thomson I., 2015, 'But Does Sustainability need Capitalism or an Integrated Report' a Commentary on 'The International Integrated Reporting Council: A Story of Failure' by Flower, J., Critical Perspectives on Accounting, vol. 27, s. 18-22.

United Nations, 1987, Our Common Future, Report of the Commission on Environment and Development, New York.

United Nations, 2002, Report of the Word Summit of Sustainable Development, New York. 